\title{
Investigating Iranian High School EFL Learners' Spelling Errors
}

\author{
Tayebeh Noory \\ Department of ELT, Kermanshah Science and Research Branch \\ Islamic Azad University, Kermanshah, Iran \\ $\&$ \\ Department of ELT, College of Literature and Humanities, Kermanshah Branch \\ Islamic Azad University, Kermanshah, Iran \\ Tel: 98-93-5842-5064 E-mail: tayebehnouri60@gmail.com

\begin{abstract}
Majid Farahian
Department of ELT, College of Literature and Humanities, Kermanshah Branch, Islamic Azad University, Kermanshah, Iran

Tel: 98-91-8333-3147_E-mail: farahian@iauksh.ac.ir
\end{abstract}

Received: Feb. 3, 2016 Accepted: March 22, 2016 Published: May 1, 2016

doi:10.5296/jse.v6i2.8971 URL: http://dx.doi.org/10.5296/jse.v6i2.8971

\begin{abstract}
The present study investigated the types of spelling errors that Iranian high school EFL learners made. It also aimed at finding whether there is a significant difference in the number of occurrence of each type of spelling error. To attain the purpose of the study, 110 third grade high school students were selected to participate in this study. The participants took a dictation test. As the next step, the participants' spelling errors were classified according to Cook's (1999) classification which includes omission errors, substitution errors, transposition errors, and insertion errors. The results demonstrated that the learners made omission errors more than other types of errors. The findings of this study also showed that the difference between the frequencies of errors was statistically different. The findings have implications for pedagogy as well as for further research.
\end{abstract}

Keywords: Spelling errors, omission errors, substitution errors, transposition errors, insertion errors, EFL learners 


\section{Introduction}

Writing is one of the important skills in language learning. To learn a language and to have a meaningful communication, writing skill has a special status. It is via writing that an individual is able to communicate and send a variety of messages to the reader. Writing is an act of communication which causes an interactive process between the writer and the reader via the text. As such, writing needs to be encouraged during the language courses.

In order to master a language, the person must not only be able to read and write, but to spell correctly as well. It is extremely important in the modern world, whether the interaction takes the form of traditional paper-and-pencil writing or an up to date digital message on a computer, a cell phone or any other technological device (Olashtain, 2001). Accordingly, proficient spelling which is the changing of linguistic forms in to written forms. is a very important indicator of a person's language proficiency (Brindle, Graham, Harris \& Sandmel, 2009).

A lot of research studies (e.g. Rodrigues \& Brown, 1987; Odisho, 1994) have been carried out on spelling in young children and they have revealed the importance of spelling. As the studies report, despite the crucial role of spelling, EFL learners seem to have increasing difficulties with spelling compared to the past (Claes and Moeyaert, 2003 cited in Vanderswalmen, Vrijders \& Desoete; 2010).There have been speculations on the reasons for the deficiency. As Vanderswalmen et al.(2010) argue, the first reason is the priorities in language teaching. In most of the EFL courses the teachers' main focus is not on spelling and they overemphasize the macro level writing processes (i.e., planning, organization and self-monitoring). The other reason is the use of new communication technologies to send written messages. This means that because of the speed of communication, less attention is being paid to proper and appropriate language. Third, the students often lack the attitude and self-awareness of proficient spellers (Vanderswalmenet al., 2010). Although some of the EFL learners make a lot of spelling errors, they are not aware of these errors and they seldom try to correct them.

Some researchers have made attempts to investigate the types of learners' spelling errors. They use different classification of spelling errors (e.g. Cook, 1999; Oller, 1978; Ott, 2007) . Among various classifications Al-Zuoud and Kabilan (2013) examined the spelling errors made by EFL learners. In this study the researchers adopted Cook's classification of EFL learners spelling errors which categorize errors into four categories:

1. Omission: errors that occur when students omit a letter in the target word.

2. Substitution: errors that occur when students substitute a letter by another one.

3. Transposition: errors that occur when students reverse the order of two letters or more.

4. Insertion: errors that occur when students add a letter to the target word.

Spelling plays an important role in EFL context since accurate spelling is required to convey messages effectively and misspelling may change the meaning that the author wants to convey. Accordingly, the present study sought the answer to the following questions: 


\section{Macrothink}

1. What types of spelling errors do Iranian high school EFL learners make?

2. Is there any significant difference in the frequency of each type of spelling errors?

\section{Methods}

\subsection{Design}

This study is a mixture of both qualitative and quantitative research in which the researchers used a dictation test to measure the participants' spelling performance.

\subsection{Participants}

A total of 110 Iranian third grade high school female students participated in this study. The researchers selected the intact classes from three high schools in Kermanshah, a city in west of Iran. The participants were EFL learners and all of them were native speakers of Persian.

\subsection{Procedure}

First the researchers did a pilot study and asked some of the randomly selected participants to take a dictation test to find the words with which they had more writing errors. After doing the pilot study, the researchers started the remaining stages of the research.

Next, the participants took the dictation test. The test was dictated in the following way. First, the words were read aloud and the students had to write them down. After dictating all the words, the complete dictation test was read aloud once more to give the students the opportunity to check their errors.

\subsection{Data Analysis}

To measure spelling performance of participants, the dictation test was scored by counting the number of spelling errors. Also the errors were classified in four main categories based on the classification presented by Cook (1999). To measure whether there is a significant difference in the frequency of each spelling error for each participants, the researchers used a Chi- Square test.

\section{Results}

In the present study the researchers scored the dictation test to find different types of spelling errors. Table 1 shows the classification of spelling errors and some examples of spelling errors that the participants made. 
Table 1. Classification of Participants' Spelling Errors

\begin{tabular}{lll}
\hline Type of spelling error & Example of errors & Correct spelling \\
\hline $\begin{array}{l}\text { Omission } \\
\text { keep accunts }\end{array}$ & $\begin{array}{c}\text { instad } \\
\text { keep accounts } \\
\text { fritened }\end{array}$ & instead \\
\hline Insertion & meall & \\
amuosing & amusing & meal \\
& keep accountes & keep accounts \\
\hline Substitution & emusing & amusing \\
& cotten & cotton \\
& feer & fear \\
\hline Transposition & wier & wire \\
& fier & fear \\
\hline
\end{tabular}

As the next step, descriptive statistics of different types of spelling errors were computed.

The results of descriptive statistics showed that Iranian high school EFL learners made omission errors more than other types of errors.

Table 2. Chi-Square Test of Frequencies of Each Type of Spelling Errors

Observed N Expected N Residual

Based on Table 2, 35 participants made no spelling errors. The most common spelling errors of 52 participants were omission errors and the most spelling errors of 3 participants were insertion errors. 16 participants made substitution errors more than other types of errors and the most spelling errors of 1 person was transposition errors. The other 3 learners made equal number of different types of spelling errors.

Table 3. Test Statistics of Chi-Square Test of Spelling Errors

\section{Spelling errors}

Chi-Squar1.193E2 ${ }^{\mathrm{a}}$

Df5

Asymp. Sig..000

The computed Chi-Square test for different types of spelling errors was 1.193 with $\mathrm{df}=5$ and Sig $=0.000$. So, because the Sig $(0.000)<0.05$, the difference between the frequency of errors was statistically a significant difference. In other words, the most common error type among Iranian EFL high school learners was omission error and the least common error was transposition errors. 
The participants of this study made 599 spelling errors, Which 307 of errors $(51.2 \%)$ were omission errors, $186(31.2 \%)$ were substitution errors, 77(12.8\%) were insertion errors, and 29 $(4.8 \%)$ were transposition errors.

Table 4. Number and Percent of Spelling Errors

\begin{tabular}{rcc}
\hline Type of error & Number of errors & Percent of errors \\
\hline Omission & 307 & 51.2 \\
\hline Substitution & 186 & 31.2 \\
\hline Insertion & 77 & 12.8 \\
\hline Transposition & 29 & 4.8 \\
\hline Total & 599 & \\
\hline
\end{tabular}

According to the above Table, the number and percent of omission errors are more than other types of spelling errors.

\section{Discussion}

To answer the first research question regarding the types of spelling errors the dictation tests were scored and the EFL learners' spelling errors were classified in to four main types of spelling errors. After performing the Chi-Square, the results showed that the learners made omission errors (51\%) more than other types of errors. The finding seems to be in tandem with Al-Zuoud and Kabilan (2013) who investigated EFL learners' spelling errors and reported that students made omission errors more than other types of errors. These researchers also found that there is another type of spelling errors related to technical errors, such as capitalization. Al-Zuoud and Kabilan (2013) stated that because the EFL learners do not know the actual sound system of English, so they use the wrong letters and make spelling errors.

Many other researchers have investigated the types of spelling errors and the causes of these errors. Some of these scholars, as cited in Bancha (2013), (Al-Hassan, 2011; Bahloul, 2007; Jayousi, 2011; Smith, 1973) agree on the fact that the first main cause of spelling errors is irregularities of the English spelling system. This fact that spelling is inconsistent makes it more difficult and requires more effort to memorize the correct spelling of words. So the learners have to put more attention to correct spelling of words (Bancha, 2013, p.3). Some other causes of misspelling are the results of linguistic differences between English and learners' first language (Brown 2000).

\section{Conclusion}

The findings showed that learners make omission errors more than other types of errors. It means that learners omit one or more letters of a word in their spelling. Moreover, learners make transposition errors less than other errors. Although most of the EFL learners commit all types of spelling errors, but the frequency of omission errors are more than other types of errors. The findings of this study also demonstrated that there is a statistically significant difference in the frequency of each type of spelling errors. 
In terms of English spelling, EFL students usually have difficulties in memorizing English words. Promoting students' attention to find their spelling errors may help them identify their problems in English spelling. Thus it is worthwhile for teachers to help students to become more proficient in spelling. Teachers are also suggested to focus their attention on learners, spelling performance to find the types of spelling errors and to help the learners to become aware of these errors and correct them in their writing.

This study was limited to a specific group of EFL learners. Further research studies are needed to replicate the study with different groups of EFL learners. Moreover, the present study did not focus on different genders, so, replicating this research to compare the performance of male and female learners is recommended.

\section{References}

Al-Zuoud, K. M., \& Kabilan, M. K. (2013). Investigating Jordanian EFL students' spelling errors at tertiary level. International journal of linguistics, 5(3), 164-176. http://dx.doi.org/10.5296/ijl.v5i3.3932

Bancha, W. (2013). What causes spelling errors of Thai EFL students. ARECLS, 10, 107-129.

Brown, H.D. (2000). Principles of language learning and teaching (4th ed.). New York: Pearson Education.

Cook, V. J. (1999). Teaching spelling. Retrieved May 17, 2002 from http:// privatewww.essex.ac. uk/ vcook/OBS20. htm

Harris, K. R., Graham, S. Brindle, M., \& Sandmel, K. (2009). In Hacker, D. J., Dunlosky\&Graesser, A. C. (Eds.), Handbook of metacognition (pp. 131-153). New York, NY: Routledge.

Odisho, E. Y. (1994). The alphabet and spelling connection: insights from non-native learners of English. ERIC Document Reproduction Service NO. ED371604.

Oller, J. W.Jr. (1978). Language tests at school. London: Longman group limited.

Olshtain, E. (2001). Practical tasks for mastering the mechanics of writing and going just beyond. M. Celce-Murcia, D. M. Brinton \& M.A. Snow (Eds.), Teaching English as a second or foreign language (pp.208-221). National Geographic Learning, Boston.

Ott, P. (2014). How to manage spelling successfully. New York: Routledge.

Rodriguez-Brown, F. (1987). Testing the transfer paradigm in second language learning; The case of spelling skills. ERIC Document Reproduction Service No.ED 336965.

Steffler, D. J., \& Varnhagen, C. K. (1998). There are more to children's spelling than the errors they make: Strategic and automatic processes for one-syllable words. Journal of educational psychology, 30, 492-505. http://dx.doi.org/10.1037/0022-0663.90.3.492

Vanderswalmen, R., Vrijders, J., \& Desoete, A. (2010). Metacognition and spelling performance in college students. In A. Efklides \& P. Misailidi (Eds.), Trends and prospects in metacognition research (pp. 367-394). Netherland: Springer. http://dx.doi.org/10.1007/978-1-4419-6546-2_17 